\title{
PENERAPAN MEDIA KANTONG AJAIB DORAEMON DENGAN MODEL OMEAKE UNTUK MENINGKATKAN KEMAMPUAN MEMBUAT KALIMAT TANYA SISWA KELAS V SDN SUKOANYAR 01 MALANG
}

\author{
Dyan Faridha $^{1}$, Bambang Yulianto ${ }^{2}$, Kisyani Laksono ${ }^{3}$ \\ Pendidikan Dasar, Pascasarjana Universitas Negeri Surabaya \\ Email: dyan.faridha@yahoo.com
}

\begin{abstract}
Abstrak
Tujuan penelitian ini adalah (1) mendeskripsikan perencanaan pembelajaran menggunakan media Kantong Ajaib Doraemon dalam model OMEAKE dalam rangka meningkatkan kemampuan membuat kalimat tanya, (2) mendeskripsikan pelaksanaan pembelajaran menggunakan media Kantong Ajaib Doraemon dengan model OMEAKE dalam rangka meningkatkan kemampuan membuat kalimat tanya, dan (3) mendeskripsikan peningkatan kemampuan siswa dalam membuat kalimat tanya dalam pembelajaran menggunakan media Kantong Ajaib Doraemon dengan model OMEAKE. Oleh karena itu penelitian ini menggunakan Penelitian Tindakan Kelas (PTK). Subjek penelitian adalah siswa kelas V SDN Sukoanyar 01 Kecamatan Wajak Kabupaten Malang, dengan jumlah 19 orang siswa yang terdiri dari 12 orang laki-laki dan 5 orang perempuan. Teknik pengumpulan data yang digunakan meliputi observasi, wawancara, dokumentasi, dan tes. Penelitian dilaksankan dalam 2 siklus, setiap siklus terdiri atas perencanaan, pelaksanaan, observasi, dan refleksi sesuai dengan model Kemmis dan Taggart. Hasil penelitian menunjukkan bahwa (1) perencanaan pembelajaran yang dibuat mengalami peningkatan disetiap siklusnya, (2) dalam pelaksanaan pembelajaran, aktivitas guru dan siswa mengalami peningkatan di setiap siklusnya, (3) pada siklus I kemampuan membuat kalimat tanya dengan menggunakan media Kantung Ajaib Doraemon dengan Model OMEAKE mencapai 63\% siswa tuntas belajarnya dan meningkat menjadi $89 \%$ pada siklus II. Berdasarkan hasil penelitian dapat disimpulkan bahwa penerapan media Kantung Ajaib Doraemon dengan Model OMEAKE dapat meningkatkan kemampuan siswa dalam membuat kalimat tanya di kelas V SDN Sukoanyar 01 Kecamatan Wajak Kabupaten Malang.
\end{abstract}

Kata Kunci: media kantung ajaib Doraemon, model OMEAKE, kemampuan membuat kalimat tanya

\begin{abstract}
The purposes of this research are (1) describe learning planning using Doraemons's Magic Pocket in OMEAKE Model for increase making question sentence ability, (2) describe learning implementation using Doraemons's Magic Pocket with OMEAKE Model for increase making question sentence ability, and (3) describe enhancement of student ability to make question sentence in learning activity using Doraemon's Magic Pocket media with OMEAKE model. Cause it this research use Class Action Study (PTK). This research subject is fifth-grade student of Sukoanyar 01 Primary School in Wajak District Malang, with total 19 students that contain 12 male and 5 female. Data Collecting Technique that used include observation, interview, documentation and making some test. The research held in two cycles, every cycle consist of planning, implementation, observation, and reflection according to Kemmis and Taggart model. The research result show that: (1) leraning planning that made increase in every cycle, (2) teacher and students activity learning implementation increase in every cycle, (3) at first cycle, ability to make question sentence using Doraemon's magic pocket media with OMEAKE Model reach 63\% students have complete the study target and increased to $89 \%$ at second cycle. According to the research result can be conclude that application of Doraemon's Magic Pocket media with OMEAKE model can increase student ability making question sentence in the fifth-grade class of Sukoanyar 01 Primary School in Wajak District Malang.
\end{abstract}

Keyword: Doraemon's Magic Pocket media, OMEAKE model, making question sentences ability of student

\section{PENDAHULUAN}

Pembelajaran menulis di SD merupakan dasar untuk tingkat pendidikan yang lebih tinggi. Penanaman konsep menulis harus benar-benar dimantapkan di SD. Salah satu bentuk keterampilan menulis adalah membuat kalimat yang diawali dengan belajar menulis huruf, menggabungkan menjadi suku kata, menyusunnya menjadi kata dan merangkainya menjadi kalimat (Haryadi dan Zamzani, 1996:75). Materi pembelajaran keterampilan menulis di SD sangat beragam, diantaranya yakni menulis kalimat. Kemampuan 
anak dalam membuat kalimat akan mempengaruhi keterampilan-keterampilan bahasa anak seperti keterampilan berbicara, bercerita maupun bertanya. Pembelajaran membuat kalimat dipelajari dari kelas I sampai kelas VI SD. Kalimat-kalimat yang dipelajari mulai dari kalimat sederhana, kalimat perintah sampai dengan kalimat tanya juga dipelajari di SD. Pembelajaran kalimat tanya di SD dimulai sejak kelas II. Sampai kelas V masih terdapat materi kalimat tanya dengan konsep yang lebih ditingkatkan.

Pada observasi awal yang diadakan peneliti pada hari Sabtu, tanggal 19 Desember 2015 ditemukan permasalahan siswa kurang dapat membuat kalimat tanya dengan benar. Dari 19 orang siswa, hanya 8 orang siswa (42\%) yang dapat membuat kalimat tanya dengan benar. Hal tersebut dibuktikan dengan diperolehnya hasil evaluasi siswa yang nilainya lebih dari KKM. Nilai KKM siswa yang ditetapkan untuk mata pelajaran Bahasa Indonesia adalah 70. Berarti 11 orang siswa (58\%) mendapat nilai dibawah KKM, sehingga dapat dikatakan mereka belum dapat membuat kalimat tanya dengan benar. Materi keterampilan bertanya di kelas $\mathrm{V}$ dikompetensikan dengan membuat kalimat tanya berdasarkan paragraf yang telah disediakan. Siswa masih banyak yang merasa kesulitan dengan menggunakan kata tanya tertentu. Rata-rata mereka kesulitan dalam memahami dan membuat kalimat tanya dengan kata tanya "bagaimana" dan "mengapa".

Kondisi tersebut dikhawatirkan akan memengaruhi kemampuan siswa dalam pembelajaran kalimat tanya dikelas VI nantinya karena materi kalimat tanya juga termasuk dalam materi ujian sekolah dikelas VI. Hal itu terbukti dari kisi-kisi dan soal-soal ujian sekolah selama 3 tahun sebelumnya, materi kalimat tanya selalu muncul. Oleh sebab itu perlu ada penyeleseian masalah agar hasil belajar dan kemampuan siswa meningkat khususnya dalam membuat kalimat tanya. Perlu diadakan penelitian untuk mengatasi masalah tersebut. Penelitian yang sesuai adalah PTK karena bahan kajian masalah yang akan diselesaikan adalah masalah pembelajaran di kelas. Sesuai dengan pendapat Akbar (2008:28) penelitian tindakan kelas dilakukan secara bersiklus dengan tujuan untuk meningkatkan aktifitas dan hasil pembelajaran di kelas tertentu.

Penyebab rendahnya hasil belajar siswa adalah (1) aktivitas yang hanya berpusat pada guru, menyebabkan siswa kurang aktif dalam proses pembelajaran; (2) guru hanya menggunakan metode ceramah, dimana setelah menjelaskan materi, memberi contoh soal kemudian memberikan soal kepada siswa; (3) guru tidak menggunakan media/alat peraga dalam menyampaikan materi membuat kalimat tanya. Hayati, dkk (2014: 3) berpendapat seharusnya guru harus lebih mampu untuk meningkatkan kreativitas siswa, mampu berinovasi, dan meningkatkan kemampuan berpikir kreatif siswa. Kepiawaian guru memilih dan menggunakan strategi pembelajaran akan sangat menentukan keberhasilan siswa (Khasanah, 2014:227). Oleh sebab itu, perlu adanya suatu terobosan yang dilakukan guru dalam meningkatkan hasil belajar siswa untuk dapat membuat kalimat tanya dengan baik dan benar.

Setelah membaca berbagai sumber, peneliti menemukan solusi pemecahan masalah tersebut. Selain penggunaan media kartu kata, peningkatan kemampuan membuat/menulis kalimat tanya menurut Subana dan Sunarti (2011:212-213) dapat dilakukan dengan teknik permainan silang datar (across and down), Category bingo, dan Spelling Bee. Penggunaan model pembelajaran kooperatif dengan berbagai tipe yaitu TGT, Snowball Throwing dan Jigsaw juga bisa dijadikan alternatif model pembelajaran dalam membuat kalimat tanya. Yusniva (2014: 52) menjabarkan alternatif cara meningkatkan kemampuan menulis siswa melalui metode belajar kelompok tipe CIRC (Cooperative Integrated Reading and Composition) atau pengajaran kooperatif terpadu membaca dan menulis, model pembelajaran langsung. Tetapi dalam penelitian ini peneliti berusaha untuk membuat media lain yang dapat meningkatkan hasil belajar siswa dalam membuat kalimat tanya dalam proses belajar mengajar. Selain itu peneliti juga berusaha membuat media yang menarik bagi siswa dan meningkatkan keaktifan mereka untuk mengikuti pembelajaran. Terinspirasi adanya pameran "100 Gadget Doraemon" yang berlangsung di Surabaya, peneliti kemudian menerapkan Kantong Ajaib Doraemon sebagai media pembelajaran dalam penelitiannya. Penggunaan media Kantong Ajaib Doraemon digunakan dalam penelitian karena peneliti beranggapan bahwa media ini sangat dikenali oleh anak-anak terutama anak usia sekolah dasar.

Dalam membuat media penulis peranggapan bahwa akan lebih bermakna jika suatu media pembelajaran merupakan sesuatu yang dikenal dilingkungan pebelajar yang dalam hal ini adalah 
anak-anak sekolah dasar. Karakteristik mereka yang senang melakukan permainan konstruktif dan olahraga meranggsang penulis untuk membuat media tersebut. Kurnia, dkk (2008:22) mengemukakan bahwa anak usia SD senang permainan olahraga, menjelajah daerah-daerah baru, mengumpulkan benda-benda tertentu, menikmati hiburan seperti membaca komik, menonton film dan televisi.

Setelah membuat media, peneliti perlu juga untuk menentukan model pembelajaran yang akan digunakan dalam menerapkan media Kantong Ajaib Doraemon yang dibuat. Pemilihan model pembelajaran didasarkan pada model pembelajaran yang relevan dengan teori belajar Behavioris, Nativisme, dan Fungsional. Selain itu model pembelajaran juga harus didukung model pengelolaan kelas secara langsung, kontekstual, kooperatif, pembelajaran kuantum dan pembelajaran berbasis masalah. Nieveen (1999:127) menyatakan bahwa suatu model berkualitas baik jika memenuhi criteria kevalidan (validity), kepraktisan (practically), dan keefektifan (effectiveness). Alternatif model pembelajaran yang sesuai dengan penjabaran tersebut dan dapat mengaplikasikan media yang digunakan peneliti adalah model pembelajaran OMEAKE.

Model pembelajaran OMEAKE dikembangkan oleh Yulianto, dkk. Nama metode ini diambil dari singkatan kata-kata kunci pada sintaks yang digunakan dalam pembelajaran yaitu Orientasi, Model, Eksplorasi, Analisis, Komunikasi, dan Evaluasi. Mengingat tujuan model pembelajaran ini menurut Yulianto, dkk (2009:27) yaitu mengembangkan kerangka berpikir yang dapat dipedomani oleh guru dan perancang pembelajaran untuk merencanakan dan melaksanakan pembelajaran yang mampu mengeksplorasi, mengoptimalisasikan, dan memperdayakan seluruh potensi siswa melalui hati, olah pikir, olah rasa, dan olah raga.

Berdasarkan paparan yang telah dikemukakan maka peneliti membuat penelitian tindakan kelas dengan judul "Penerapan Media Kantong Ajaib Doraemon dengan Model OMEAKE untuk Meningkatkan Kemampuan Membuat Kalimat Tanya Siswa Kelas V SDN Sukoanyar 01 Malang".

\section{METODE}

Penelitian yang digunakan dalam penelitian ini adalah kualitatif. Jenis penelitian yang dilakukan adalah termasuk dalam Penelitian Tindakan Kelas (classroom action research). Penelitian Tindakan Kelas yang dilakukan peneliti digunakan untuk memahami kekurangan, dan memperbaiki pembelajaran. Proses pemecahan masalah tersebut dilakukan secara bersiklus dengan tujuan untuk meningkatkan aktifitas dan hasil pembelajaran. Terutama masalah dalam meningkatkan kemampuan membuat kalimat tanya pada siswa kelas V.

Pelaksanaan penelitian dilakukan dalam beberapa tahap yaitu: siklus I dan siklus II. Model Siklus yang dikembangkan oleh Kemmis \& Taggart merupakan model siklus penelitian tindakan kelas yang digunakan oleh peneliti. Tahap-tahap yang digunakan oleh Kemmis \& Taggart.

Pada setiap siklus terdiri atas meliputi planning (perencanaan), action and observing (pelaksanaan tindakan dan observasi), reflection (refleksi), dan revise plan (perbaikan perencanaan).

\section{HASIL DAN PEMBAHASAN}

\section{A. Perencanaan Pembelajaran}

Secara keseluruhan validator menganggap bahwa RPP yang dibuat peneliti cukup baik dan dapat digunakan dengan revisi kecil. Hasil validasi kebahasaan dan keterbacaan cerita Doraemon yang digunakan dalam penelitian cukup baik dan dapat digunakan dengan revisi kecil. Sedangkan hasil validasi media pembelajaran cukup baik. Setelah dilakukan validasi pada perangkat pembelajaran, peneliti mulai dapat menggunakan perangkat pembelajaran tersebut dalam pembelajaran. Untuk RPP hasil dari validasi oleh validator digunakan dalam kegiatan berikut.

Observer menganggap bahwa RPP pada siklus I yang dibuat peneliti cukup baik dengan revisi kecil. Komentar dari observator yaitu pembagian kelompok kurang merata karena melalui pengundian dan saat anak membaca cerita di depan kelas suara kurang keras sehingga anak yang lain kurang bisa menyimak. Komentar tersebut menjadi bahan kajian untuk peneliti memperbaiki RPP di siklus II.

RPP pada Siklus II Setelah melakukan refleksi dan perbaikan RPP sesuai dengan saran dan catatan guru pamong siklus I, peneliti membuat RPP baru hasil revisi untuk siklus II. Observer menganggap bahwa RPP yang dibuat peneliti baik dan ada peningkatan dari siklus I. Observer tidak memberikan komentar apapun. 
B. Pelaksanaan Pembelajaran

1. Keterlaksaan RPP

Siklus I dilaksanakan pada hari Sabtu tanggal 4 Juni 2016. Nilai perolehan aktivitas guru pada siklus I keseluruhan adalah 77. Siklus II dilaksanakan pada hari Kamis tanggal 9 Juni 2016. Nilai perolehan aktivitas guru pada siklus II keseluruhan adalah 88. Dapat dikatakan aktivitas guru baik dan usaha guru untuk meningkatkan nilai berhasil.

\section{Aktivitas Siswa}

Hasil pengamatan aktivitas siswa pada siklus I diperoleh nilai rata-rata aktivitas siswa adalah 66. Nilai rata-rata yang diperoleh pada siklus II untuk aktivitas siswa meningkat menjadi 92. Pada Siklus I rata-rata nilai adalah 66 , kemudian naik menjadi 92 pada siklus II. Berarti terjadi peningkatan 26 poin dalam aktivitas siswa.

3. Respons Siswa

Hasil pengamatan respon siswa setelah melakukan pembelajaran sebagai berikut: a) mereka senang dengan cara guru mengaitkan materi pelajaran dengan pengetahuan yang dimilikinya, siswa juga senang dengan cara guru bertanya dan menjawab pertanyaan, b) semua siswa menganggap media yang digunakan guru mudah, c) sebagian besar siswa berminat mengikuti pembelajaran dengn menggunakan model OMEAKE dan berminat pula jika model tersebut diterapkan lagi dalam pembelajaran, dan d) sebagain besar siswa menjawab "ya" bahwa media kantung ajaib Doraemon dan model pembelajaran OMEAKE memudahkan mereka dalam menyerap materi pelajaran.

C. Kemampuan Membuat Kalimat Tanya

Hasil evaluasi yang diperoleh pada siklus I siswa yang tuntas (memenuhi nilai KKM yaitu 70) dalam pembelajaran ada $12(63 \%)$ siswa, sedangkan siswa yang belum tuntas ada 7 (37\%) siswa. Hasil evaluasi siklus II siswa yang tuntas (memenuhi nilai KKM yaitu 70) dalam pembelajaran ada 17 (89\%) siswa, sedangkan siswa yang belum tuntas ada $2(11 \%)$ siswa. Karena target $85 \%$ siswa tuntas belajar sudah terpenuhi maka penelitian dihentikan. Rekapitulasi hasil evaluasi membuat kalimat tanya sebagai berikut.

Dari data tersebut dapat diketahui pula kenaikan ketuntasan klasikal hasil belajar membuat kalimat tanya siswa. Peningkatan ketuntasan klasikal hasil belajar membuat kalimat tanya membuahkan hasil yang bagus. Dari rata-rata ketuntasan klasikal awal observasi hanya $60 \%$, kemudian naik menjadi $69 \%$ pada siklus I dan naik lagi menjadi $84 \%$.

\section{PENUTUP}

Berdasarkan hasil penelitian dapat ditarik kesimpulan sebagai berikut.

1) RPP yang dibuat telah memenuhi standar kualifikasi yang ditentukan.

2) Pelaksanaan Pembelajaran terangkum dalam beberapa hal berikut.

a) Keterlaksanan RPP membuktikan adanya peningkatan terhadap aktivitas guru yang lebih baik dalam pembelajaran.

b) Aktivitas siswa meningkat dalam proses pembelajaran, hal ini berdampak baik bagi siswa.

c) Respons siswa terhadap penggunaan media kantung ajaib Doraemon dan model pembelajaran OMEAKE dalam pembelajaran disambut baik, setuju, senang, dan berminat melaksanakan pembelajaran.

3) Peningkatan kemampuan siswa dalam membuat kalimat tanya telah mencapai target.

Saran yang diberikan oleh peneliti sebagai berikut.

1) Guru hendaknya mempersiapkan perangkat pembelajaran dengan teliti dan seksama sebelum pelaksanaan pembelajaran.

2) Guru diharapkan menggunakan berbagai metode dan teknik serta media maupun alat peraga sebagai sarana penyampaian materi pelajaran.

Pemberian reward dapat memotivasi siswa dalam mengikuti pembelajaran

\section{DAFTAR PUSTAKA}

Akbar, S. 2008. Penelitian Tindakan Kelas. Malang: Surya Pena Gemilang.

Arsyad, Azhar. 2010. Model-Model, Media, dan StrategiPembelajaran Kontekstual (Inovatif). Bandung: Yrama Widya.

Djamarah, Syaiful Bahri dan Aswan, Zein.2002. Strategi Belajar Mengajar. Jakarta: Rineka Cipta.

Faisal, Muh .dkk. 2010. Bahan Ajar Cetak Kajian Bahasa Indonesia. Jakarta: DIRJEN DIKTI

Hairuddin. dkk. 2008. Bahan Ajar Cetak Pembelajaran Bahasa Indonesia. Jakarta: DIRJEN DIKTI 
Haryadi dan Zamzani. 1996. Peningkatan

Keterampilan Berbahasa Indonesia. Jakarta: Depdikbud.

Hayati, Ima Mala. dkk. 2014. "Pengembangan Perangkat Pembelajaran Terpadu Tipe Threded untuk Melatih Keterampilan Berpikir Kreatif pada Siswa Sekolah Dasar". Dalam Pendidikan Dasar (Jurnal Kajian Teori dan Hasil Penelitian). 1 (Juli, III). Surabaya.

https://ekasafitri22.wordpress.com. 2016. "Kerucut Pengalaman Dale".10 Januari.

Iskak, Ahmad dan Yustinah. 2008. Bahasa Indonesia Tataran Semenjana untuk SMK dan MAK Kelas X. Jakarta: ERLANGGA.

Khasanah, Uswatun. 2014. "Penggunaan Metode Bercerita Bermedia Boneka Tangan untuk Meningkatkan Kemampuan Bercerita Anak". Dalam Pendidikan Dasar (Jurnal Kajian Teori dan Hasil Penelitian). 2 (Januari, II). Surabaya.

Kurnia, Ingridwati. Dkk. Bahan Ajar Cetak Perkembangan Belajar Peserta Didik. Jakarta: DIRJEN DIKTI.

Lambirth, Andrew. 2010. "Class Consciousness, Power, Identity, and the Motivation to Teach". Dalam Power and Education Volume 2, 2. School of Education, University of Greenwich, United Kingdom.

Maloney, Erin A. 2015. "Jump-Starting Early Childhood Education at Home: Early Learning, Parent Motivation, and Public Policy". Dalam Perspectives on Psychological Science, Volume 10, 6. Assosiation for Psychologycal Science. SAGE Publish.

Nieveen, Nieke. 1999. Prototy to reach product Quality. In Jan Vanden Akker, R. M. Brach, Gutafson, H. Nieveen and $\mathrm{Tj}$ Ploom (Eds). Dalam Design Approaches and Tools in Education and Trining. Dogrecht, Netherland. Kluwer Academic Publiser.

Sadiman, Arief dkk. 2014.Media Pendidikan, Pengertian, pengembangan, dan Pemanfaatannya. Jakarta: PT Raja Grafindo Persada.

Siahaan, Sanggam. 2008. Issues in Linguistics. Yogyakarta: Graha Ilmu.

Sroufe, L. Alan dan Cooper, Robert G. 1988. Child Development its Nature and Course. New York: McGraw-Hill Publishing Company.

Subana, M. dan Sunarti. 2011. Strategi Belajar Mengajar Bahasa Indonesia (Berbagai
Pendekatan, Metode Teknik, dan Media Pengajaran). Bandung: PUSTAKA SETIA.

Tsukamoto, Miho. 2014. Educational and Technological Perspectives in Doraemon Hope and Dreams in Doraemon's Gadgets. Dalam International Journal of Social, Behavioral, Educational, Economic, Business and Industrial Engineering, Volume 8, 11. World Academy of Science, Engineering and Technology.

Tushi, Tasmania Ekram. 2014. "The Case of Bangladesh Government Banning Japanese Manga Cartoon Show Doraemon: The Antecedents of Consumers' Avoidance". Dalam Global Journal of Management and Business Research: E Marketing, Volume 14, 1. Double Blind Peer Reviewed International Research Journal Publisher: Global Journals Inc. (USA).

Yulianto, Bambang. dkk. 2009. Model Pembelajaran Inovatif Bahasa Indonesia. Surabaya: Unesa University Press.

Yusniva. 2014. "Upaya Meningkatkan Kemampuan Menulis Siswa Sekolah Dasar Melalui Penerapan Model Lapindo". Dalam Pendidikan Dasar (Jurnal Kajian Teori dan Hasil Penelitian). 1 (Juli, III). Surabaya 